Mycologia, 101(4), 2009, pp. 535-538. DOI: 10.3852/08-029

(C) 2009 by The Mycological Society of America, Lawrence, KS 66044-8897

\title{
Geastrum episcopale: a new noticeable species with red-violet exoperidium
}

\author{
Francisco Kuhar \\ Leandro Papinutti ${ }^{1}$ \\ Laboratorio de Micología Experimental, Departamento \\ de Biodiversidad y Biología Experimental, Facultad de \\ Ciencias Exactas y Naturales, Universidad de Buenos \\ Aires, Argentina
}

\begin{abstract}
A new species, Geastrum episcopale, is described from Argentina. Detailed descriptions and illustrations of fresh and dry basidiomata are provided along with photographs of microscopic elements, such as spores, capillitium, calcium oxalate crystals, and exo- and endoperidium surfaces. This fungus is typical of the genus in its morphology and ecology but clearly differs from every known species. This species can be distinguished easily by the red-violet (to magenta) exoperidium and the lilac endoperidium. Specimens were collected on wet soil composed of a superficial layer of ca. $5 \mathrm{~cm}$ leaf litter and $15 \mathrm{~cm}$ of particulate and melanized lignocellulosic material ( $\mathrm{pH}$ 6.5) under Eugenia uruguayensis and Nectandra sp.
\end{abstract}

Key words: Gasteromycetes, Geastraceae, Geastrum, Phallomycetidae

\section{INTRODUCTION}

Genus Geastrum was established by Persoon in 1794 (and sanctioned in 1801). The group is characterized by globose to subglobose basidiomata, composed of an exoperidium that splits into a variable number of segments (rays), and a globose endoperidial body bearing a single apical pore surrounded by a nondifferentiated area of a fibrillose to plicate structure (peristome). The surface of both endoperidium and exoperidium exhibits calcium-oxalate crystals, which might play a role in the splitting of the fruitbody just before the rupture (Whitney and Arnott 1986). The shape of the calcium-oxalate crystals seems to be a constant feature of each species (Sunhede 1989). The endoperidial body contains the capillitial hyphae that radiate from the columella through the fertile tissue, forming the gleba. Mature spores are globose, and in all species of the genus exhibit a sculptured wall.

A classification based on phylogenetic molecular analysis was proposed by Hibbett et al (2007): Ph:

Accepted for publication 1 March 2009.

${ }^{1}$ Corresponding author. E-mail: leandru@bg.fcen.uba.ar
Basidiomycota; SPh: Agaricomycotina; Cl: Agaricomycetes; SCl: Phallomycetidae, and O: Geastrales. The new subclass Phallomycetidae and order Geastrales had been established by Hosaka et al (2006). The occurrence of genus Geastrum in a wide range of habitats in various parts of the world has been well documented. Many species of this genus have been described since the middle of the 19th century, and in the past 10 y seven new species, five of which occur in South America, have been described: G. ovalisporum (from Bolivia, Calonge et al 2000), G. hirsutum (from Brazil, Baseia and Calonge 2006), G. lilloi (from Argentina, Domínguez de Toledo 1996), G. setiferum (from Brazil, Baseia and Milanez 2002), G. albonigrum (from Costa Rica; Calonge and Mata 2004), G. parvistriatum (from Spain, Zamora and Calonge 2007) and G. pleosporus (from Cameroon, DouanlaMeli et al 2005). Surveys of genus Geastrum in Argentina are few, thus making it a poorly known genus in this area. Soto and Wright (2000) have recognized 13 species in Buenos Aires, suggesting that the list could be largely increased if the entire country were considered. During a photographic expedition to record the fungal diversity in the Mesopotamia (a region that comprises Misiones, Corrientes and Entre Ríos provinces) an unusual and noticeable species was found, described herein as Geastrum episcopale, a species new to science.

\section{MATERIALS AND METHODS}

This work is based on specimens collected by L. Papinutti that are deposited in BAFC and FK. Herbarium acronyms are those of Holmgren and Holmgren (1998). Capillitial threads, calcium oxalate crystals and spores were mounted and observed under a light microscope (LM) and a scanning electron microscope (SEM EDS, Inca Energy, Oxford Instruments scanning electron microscope with field emission gun [FEG] Zeiss DSM 982 Gemini secondary electron in-lens detector). To estimate the sizes of microscopic and macroscopic elements, at least 20 measurements were made and mean values $\pm \mathrm{SD}$ calculated. All LM photographs were taken from phloxine-stained slides. Colors are described according to Maertz and Paul (1930). Holotype and isotype were dried, kept frozen a week and deposited in BAFC.

RESULTS

Geastrum episcopale F. Kuhar et L. Papinutti, sp. nov. FIGS. 1-3

Carposomata saccata ad clavata, pedicellata, gregatim 

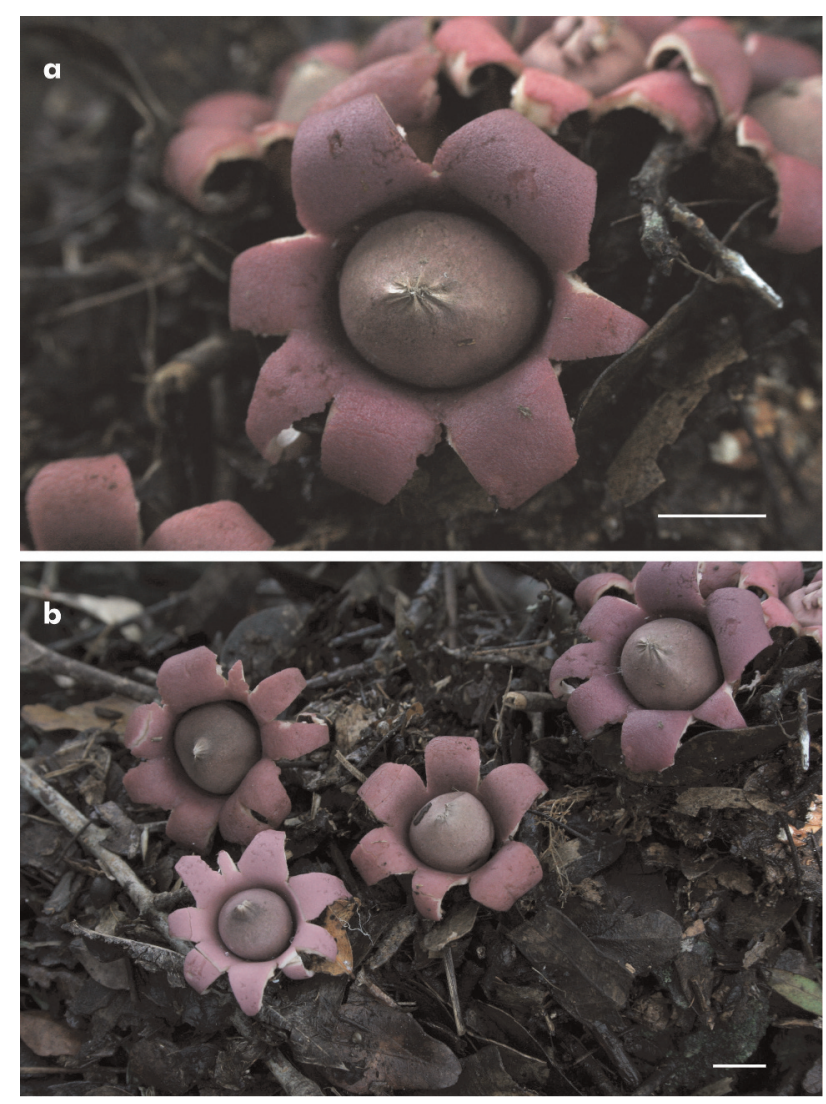

FIG. 1. Geastrum episcopale, isolated mature fruit body (a) and group (b). Note the saccate exoperidium, the unequal size of the laciniae and the different states of development of the peristomata. Bars $=1 \mathrm{~cm}$.

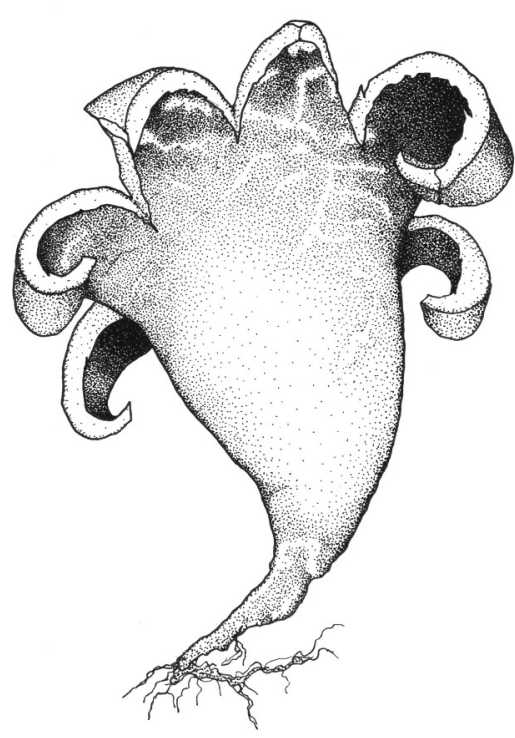

occurrentia. Mycelium basale, solum pedicello carposomatis accretum. Exoperidium ahygroscopicum, in lacinias plerumque $6-9$ persaepe 7 valde inaequales dehiscens, superficie purpureas, siccitate rufescentes et arcte involutas, deorsum rimosas. Stratum myceliale absque residuis humi. Endoperidium sessile, laeve superficie vel pruinosum, exoperidio coloribus persimile. Peristomium haud definitum, plicatum, laeviter breviterque mammiforme. Capillitium brunneum, plerumque non ramosum, maxime $8 \mu \mathrm{m}$ crassum. Sporae minusculae $2.2 \mu \mathrm{m}$ diam, verrucis obtusis exornatae. In umbra dumetorum inter madefacta folia atque putrescentia.

HOLOTYPUS: ARGENTINA. CORRIENTES: Depto. Curuzú-Cuatiá, IV-2007, Leandro Papinutti \& Guillermo Rolón, BAFC 51671.

Macroscopic characteristics: Basidiomata in mature state $2.5-3 \mathrm{~cm}$ high $\times 3.5-4.0(-4.5) \mathrm{cm}$ diam (FIG. 1a, b), gregarious on leaf litter (FIG. 1b), one-third submerged in the substrate. Immature basidiomata hemihypogeous, in lateral view with broadly mammiform apex and obconic base, brown. Endoperidial body sessile, saccate, 1.5-2 cm diam; endoperidium smooth, lilac (Pl. 44 C-4), wall papery bearing almost parallel nonprotruding hyphae (FIG. 3f); apophysis absent; peristome not truly plicate but with coarse folds in young specimens, slightly protruding and becoming fibrillose with age, neither distinctly delimited nor prominent, splitting at maturity (FIG. 2b), concolorous with the surrounding endoperidium; stalk lacking; columella absent; gleba at maturity dark brown. Exoperidium nonhygroscopic, at maturity typically splitting into 6-9 (mostly 7) rays unequal in width at the base as well as in length, recurved from the a

b

FIG. 2. Lateral view of the fresh mature fruitbody showing rhizoids (a), three different states of development in peristomata of fresh endoperidial bodies (b), dried fruitbodies with and without rhizoids (c). Bar $=1 \mathrm{~cm}$. 

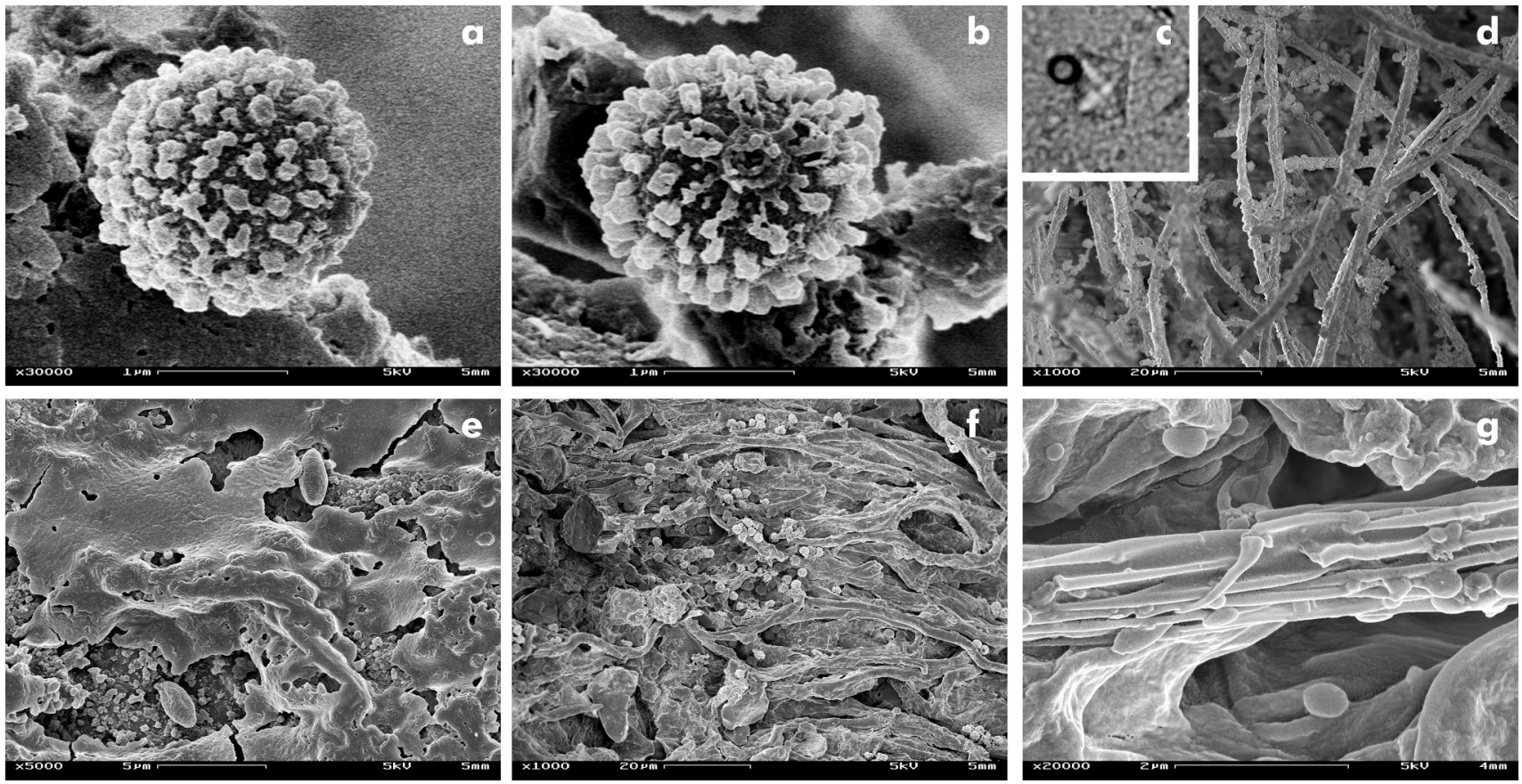

FIG. 3. Mature spores bearing short columnar processes (a and b), calcium oxalate crystal (c), capillitium showing unbranched hyphae with spores attached (d), exoperidial surface (e), endoperidial surface (f), bundle of hyphae from endoperidial surface bearing clamp connections $(\mathrm{g})$.

endoperidial body after rupture, not truly hygroscopic but the rays bent or rolled toward the endoperidial body in dry specimens; other positions also were observed (FIG. 2c). Rhizoids in the tip of the acute base of basidiomes may persist as a single, dominant axis with mycelial tufts attached (FIG. 2c); mycelial layer thin, brown, with no debris encrusted, irregularly rimose leaving the inner whitish pseudoparenchymatous layer visible, persistent in dry specimens; middle fibrous layer (exposed surface of the rays) redviolet (Pl. $52 \mathrm{~A} 10)$ to magenta (Pl. $43 \mathrm{~J} 7)$ when fresh and chestnut (Pl. 7 E6) when dry; pseudoparenchymatous layer persistent, whitish when fresh, in age changing to beige. Microscopic characteristics: spores $2.2 \pm 0.2 \mu \mathrm{m}$ diam bearing columnar processes $(0.2 \mu \mathrm{m})$ with slightly expanded tips (FIG. 3a, b), apiculus distinct (FIG. 3b); capillitial hyphae $2.6 \pm$ $0.2 \mu \mathrm{m}$ diam (FIG. 3d), with thickened walls and lumen cells visible as a straight or slightly curved line, rarely branched with spores and bipyramidal calcium-oxalate crystals attached (FIG. 3c), size of the crystalline matter is variable $(1.5-4.5 \mu \mathrm{m})$. Clamp connections of variable size and shape also were observed in many tightly adhered hyphae from the endoperidial surface but not in other tissues (FIG. 3g). Basidia were not observed due to the maturity of samples mounted for SEM.

Habit, habitat, and distribution: infrequent, gregar- ious on a thick layer of wet debris and leaf litter under Eugenia uruguayensis and Nectandra sp., $\mathrm{pH}$ 6.5, Curuzú-Cuatiá $\left(30^{\circ} 00^{\prime} 12^{\prime \prime} \mathrm{S}, 57^{\circ} 43^{\prime} 20^{\prime \prime} \mathrm{W}\right)$, Corrientes, Argentina, April (autumn). No attempts to germinate spores on common malt agar were successful.

Etymology. Episcopale refers to the purple choir cassok of Roman Catholic bishops.

Specimens examined: ARGENTINA. CORRIENTES: Depto. Curuzú-Cuatiá, IV 2007, Leandro Papinutti and Guillermo Rolón (HOLOTYPE: BAFC 51671); Depto. Ituzaingó, Rincón Ombú Chico, 25 IV 1975, L. Ferraro (BAFC $663)$.

\section{DISCUSSION}

Because morphological features vary greatly in shape and size many authors agree that spore morphology constitutes a more reliable feature for species comparisons within the genus (Sunhede 1989, Soto and Wright 2000, Douanla-Meli et al 2005). Both the size of the spores and their ornamentations appear to remain constant within a single species but appear to vary greatly among species. G. episcopale differs from all other described species of the genus, including those reported by Sunhede (1989), Soto and Wright (2000) and Bates (2004), in that they form the smallest spores. Peristome morphology is not a reliable character to identify this species due to the 
presence of plicate-like and fibrillose forms in the same group, which probably reflect different states of maturity. A similar morphological variation also was observed in G. fimbriatum (Sunhede 1989). G. episcopale and G. fimbriatum have several characteristics in common: nonhygroscopic fuitbodies, saccate exoperidia, sessile endoperidial body, indistinctly delimited peristome. However there are features that differentiate G. fimbriatum, for example the strongly encrusted debris in the mycelial layer, the presence of columella, the \pm globose unexpanded fruitbody, the not persistent pseudoparenchymatous layer and larger spores. Because G. episcopale does not encrust debris in the mycelial layer the key proposed by Stanek (in Pilát 1958) for the infrageneric categories would place this species in section Basimyceliata, near G. saccatum. Mature basidiomata differ from the morphologically closest Basimyceliata species G. saccatum (in addition to spore diameter) in the acute base connecting the fruitbody with the underlying mycelium, the rimose and persistent mycelial layer, the indistinctly delimited peristome and the absence of columella. Although the exoperidium of $G$. saccatum is mostly \pm saccate and specimens with \pm planar or arched exoperidial disks can be found (Sunhede 1989), such a characteristic was not found in G. episcopale. No matter what the circumstance is, the color of both the endoand exoperidial surfaces (fibrous layer) at maturity seems to be the best diagnostic feature in the field. The strongly pigmented surface of the mycelial layer is concomitant with species that do not encrust debris, such as G. episcopale, according to Sunhede (1989).

While comparing G. episcopale with the material deposited in the BAFC herbarium a specimen of Geastrum saccatum BAFC 663 was found that actually was shown to be equivalent to $G$. episcopale, the specimen was collected in 1975. Further periodical explorations in both sites were unsuccessful in finding fresh basidiomata. Nevertheless in 2008 several dry, old ones were found in Curuzú-Cuatiá.

The rare occurrence of G. episcopale, along with the notable abundance of other species of Geastrum found in the same season in Corrientes, might reflect either a low population density or infrequent environmental conditions for fructification.

\section{ACKNOWLEDGMENTS}

We thank Guillermo Rolón for the technical assistance with the figures. This work was supported by grants from CONICET (Consejo Nacional de Investigaciones Científicas y Técnicas), Argentina, and Universidad de Buenos Aires.

\section{LITERATURE CITED}

Baseia IG, Calonge FD. 2006. Geastrum hirsutum: a new earthstar fungus with a hairy exoperidium. Mycotaxon 95:301-304.

— Milanez AI. 2002. Geastrum setiferum (Gasteromycetes): a new species with a setose endoperidium. Mycotaxon 84:135-139.

Bates ST. 2004. Arizona members of the Geastraceae and Lycoperdaceae (Basidiomycota, Fungi) [Doctoral dissertation]. Arizona State Univ. 445 p.

Calonge FD, Mata M. 2004. A new species of Geastrum from Costa Rica and Mexico. Bol Soc Micol Madrid 28:331335.

_- Moreno-Arroyo B, Gómez J. 2000. Aportación al conocimiento de los Gasteromycetes, Basidiomycotina, de Bolivia (América del Sur) Geastrum ovalisporum sp. nov. Bol Soc Micol Madrid 25:271-276.

Domínguez de Toledo L. 1996. Geastrum lilloi sp. nov. from Argentina. Mycologia 88:858-862.

Douanla-Meli C, Langer E, Calonge FD. 2005. Geastrum pleosporus sp. nov., a new species of Geastraceae identified by morphological and molecular phylogenetic data. Mycol Prog 4:239-250.

Hibbett DS, Binder M, Bischoff JF, Blackwell M, Cannon PF, Eriksson OE, Huhndorf S, James T, Kirk PM, Lücking R, Thorsten Lumbsch H, Lutzoni F, Matheny PB, McLaughlin DJ, Powell MJ, Redhead S, Schoch CL, Spatafora ZW, et al. 2007. A higher-level phylogenetic classification of the fungi. Mycol Res 111:509-547.

Holmgren PK, Holmgren NH. 1998. Index herbariorum: a global directory of public herbaria and associated staff. New York Botanical Garden virtual herbarium. http:// sweetgum.nybg.org/ih/

Hosaka K, Bates ST, Beever RE, Castellano MA, Colgan III W, Domínguez LS, Nouhra ER, Geml J, Giachini AJ, Kenney SR, Simpson NB, Spatafora JW, Trappe JM. 2006. Molecular phylogenetics of the gomphoid-phalloid fungi with an establishment of the new subclass Phallomycetidae and two new orders. Mycologia 98:949_ 959.

Maertz A, Paul MR. 1930. Dictionary of color. 1st ed. New York: McGraw Hill Co. 207 p.

Pilát A. 1958. Gasteromycetes. Flora ČSR B1. Československé Akademie Vd, Czechoslovakia.

Soto M, Wright JE. 2000. Taxonomía del género Geastrum (Basidiomycetes, Lycoperdales) en la provincia de Buenos Aires, Argentina. Bol Soc Arg Bot 34:185202.

Sunhede S. 1989. Geastraceae (Basidiomycotina) morphology, ecology and systematics with emphasis on the north European species. Synopsis Fungorum 1. Oslo: Fungiflora. $535 \mathrm{p}$.

Whitney KD, Arnott HJ. 1986. Calcium oxalate crystals and basidiocarp dehiscence in Geastrum saccatum (Gasteromycetes). Mycologia 78:649-656.

Zamora JC, Calonge FD. 2007. Geastrum parvistriatum, una nueva especie encontrada en España. Bol Soc Micol Madrid 31:139-149. 